UDC 336.1(075.8)

JEL Classification: M31, D83

Victoria Atiushkina

Ph.D in Economics, Associate Professor

Department of Economicsand Entrepreneurship Volodymyr Dahl East Ukrainian National University

(Severodonetsk, Ukraine)

Anastasia Zhekul

Student

Department of Marketing

Odessa National Polytechnic University

(Odessa, Ukraine)

\title{
ANALYSIS OF THE IMPACT OF GOODS CHARACTERISTICS ON THE RESULTS OF PERSONAL SELLING
}

The article deals with the relationship between the characteristics of the product and the results of its selling, identifying the search direction of relevant characteristics of the goods. The article proposes an algorithm for determining the relevant characteristics of the product or service for the purpose of increasing sale due personal selling. Goods characteristics are analyzed based on their importance, influence and significance determined by the results of consumer survey in the process of personal selling. To identify the significant characteristics of the product a search area was developed, which is based on different approaches to the classification of characteristics of the product (services). The evaluation of the influence of significant characteristics (service efficiency, reliability, company reputation) on the result of the personal selling was carried out on the single example. significance.

Key words: relevant characteristics, algorithm, personal selling, influence, importance,

\section{DOI: 10.15276/mdt.3.1.2019.3}

Statement of the problem in general form and it's connection with important scientific or practical tasks. An important problem of marketing is to identify the whole set of incentive factors that affect the consumers choose a product. Such influence determines the formation in the consumer's imagination of certain selection criteria, some of which have a rational origin, it can be measured or recorded using well-known indicators. Others derive from the subjective perception of the individual, psychology of purchases, situational consumer's burden. The determination of such characteristics of the product that will be relevant to the solution of the forenamed question is an essential issue for forecasting the consumer's choice and, as a consequence, for the providing of increasing the volume of goods' sales.

Search for relevant characteristics is hampered by the fact that the seller does not always understand where to find meaningful characteristics, what exactly is the reference point of customers choose?

(C) 2019 The Authors. This is an open access article under the CC BY license (http://creativecommons.org/licenses/by/4.0/) 
Essential assistance in finding answers can be provided by direct marketing methods, and most of all -personal sales. In the process of direct communication with a potential customer, an experienced sales agent can record consumer's reactions to the product, expectations, more precisely understand consumer inquiries, etc. The use of the method of personal sales for innovation products is the most appropriate. The value created by the seller, consumer expectations and the buying process should be taken into account at the stage of goods creation. Studying these aspects is also best done through personal selling.

It should be borne in mind that consumers are people who have the will, they follow a certain psychology of consumer behavior, and they have certain preferences in the course of making a decision on the purchase of different goods. If to create a formalized scale of the benefits on buying one product to another is not possible, then the task may be to study the patterns of consumer behavior, the identification of the most significant characteristics of the product for the choice.

Analysis of the latest research and publications, which initiated the solution of this problem and on which the author relies. The connection of product characteristics and their significance to consumers' preferences and behavior has been analyzed in marketing for more than fifty years, but the possibilities of applied research not only question, another level of the problem settles in general methodological approaches. The contribution to the study of attribution, multi-attribute models was made by K. Lancaster, A. Tversky, M. Fishbein and M. Rosenberg, J. Kelly, M Johnson. The concept of human values was embodied in the works of M. Rokich.

The marketing theory uses terms saliency, importance and determinacy of product characteristics. The saliency was investigated by D. Krech and R. Krutchfield, the importance - by M. Ryan, M. Etzel, the influence - by J. Mayers and M. Elpertom.

The works of Russian scientists I.V Gladkikh, Zh. V. Svetlanova [1] is devoted to the analysis of the methods of measuring the significance of characteristics, the problem of consumer choice psychology is thoroughly investigated by O.S. Posypanova [2], the question of the relevance of the company's response to consumer inquiries is substantiated in the work of A. Coville, P. Braun [3].

Highlighting the previously unresolved parts of the general problem to which the article is devoted. The question of determining the field of search significant characteristics of the product, which affect the buyers' choice; the problem of verification of the consumer's awareness of the significance' degree of these characteristics; the identification of relevant characteristics for the purposes of increasing the consumption of goods requires further research.

Formulation of the purpose of the article (statement of the problem). The purpose of the work is to study the relationship between the characteristics of the product and the results of its selling, identify the search area of significant characteristics of the goods, the formation of an algorithm for determining the relevant characteristics of the product.

Statement of the main material of the research with full justification of the scientific results obtained. Goods and services are the economic benefits that result from human labor. Their main criterion in modern economy is the ability to meet the needs of consumers.

In connection with the huge variety of goods it is impossible to create a single, consistent and comprehensive classification. Among all the signs of classification, the main characteristic of the product is its consumer properties.

The consumer properties of products are estimated by the buyer on the following parameters:

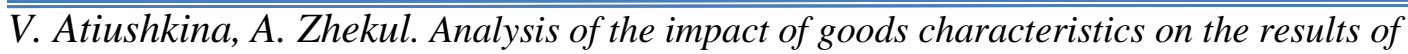
35 personal selling 
- Product category. In order to meet their needs, the general category of the product and the choice of brand are determined by the consumer in the first stage. This is mainly due to the purchase of non-consumer goods (electronics, appliances, etc.).

- Price is one of the most important parameters, related not only to the ability of the consumer to buy this product, but also to the quality of the product itself and the image of its owner.

- Functional characteristics. The consumer always considers the purchase in relation to their needs, how fully and economically the specific product may satisfy this need. The more complicated the complex needs, the longer the product life and the higher the price is the greater the list of functions of the product.

- Satisfaction with the purchase. The consumer wants to get emotional satisfaction from the process of buying a product, usually subconsciously. Satisfaction from the purchase and the result of consumption are very important criterions.

- Quality is the criterion, which is estimated by the consumer together with the previous parameters, it is guided by the objective indicators taken in the commodity research.

There is a lot common between the goods and the service. Although there are significant differences: the service is elusive, non-permanent, inseparable from the subject of its provision and incapable of preservation. And the main difference between goods and services lies in the materiality of the first one and non-materiality of the second one. All these features considerably complicate the assessment of the quality of the service provided. If the consumer properties of products can be estimated by at least objective physical criteria, then for the services are much more difficult to determine their characteristics and qualities.

Service is the object of sale in the form of actions of the performer, which give the consumer benefits or useful result. In the process of providing services does not create a new, none previously existing material product, but changes the quality of the existing, prior created product. It is a benefit provided in the form of activity or its results, but not in the form of items of consumption or exchange. It is the fact of the provision of services that contains the desired outcome for the consumer.

The features of the services and their significant differences from each other make it impossible to create a well-founded classification of services. Traditionally, they are divided according to the areas in which they are applied. It is accepted to separate medical, passenger, sports, educational, informational, bank, legal, security, veterinary services, as well as services in the field of catering, beauty, repair, cleaning and real estate.

Distinctive service features are:

- intangibility of services: services cannot be hold, heard, seen or tasted before the time of its acquisition, or at the time of receipt. This criterion is a problem for all potential buyers, because there is no guarantee that the provided service will really be of high quality;

- inseparability, production contiguity and consumption of services: services are provided and consumed at the same time that is can be provided only upon receipt of an order.

Services, unlike material goods, are initially sold, but only then they produce and consume. The inalienability of services implies that services cannot be separated from their source, regardless of who provides this service. A person will be considered a part of the service if he provides this service.

- the quality of services is not constant: the quality of services can vary considerably in depend by who, under what conditions and when they were provided. This is in contrast to material goods, the quality of which remains constant in the general sense.

- durability of services, impossibility of their storage: services cannot be stored for further use or resale. 
- lack of ownership. The consumer of the service is not the owner of the service, but only uses it for a limited time of its provision. Services do not have the owner unlike material goods. In most cases, the service cannot be used long time, because for long-term use this service becomes irrelevant to the consumer.

- interchangeability of services with material goods. The goods have ability to replace those services that meet similar needs. This feature of services may also appear in inverse relationship: services can replace goods.

Consumer properties of the service according to the criteria of selection by the consumer are the same as for goods. This is a prestige, price, category, satisfaction. But the specifics of the services provide additional consumer properties, such as:

- Reliability. The stability of the service result under the impact of various influencers has the main role.

- Effectiveness. That means ability of service to meet consumer's needs in relation to its entire set of conditions of provision.

- Reputation of the service provider. This implies the professionalism of service providers, material and technical support for equipment, and compliance needs sanitary requirements and safety standards.

The attribute of the goods is a significant feature of the product, which defines the goods in the customer perception as suitable for him. That is, the attribute is not all the signs of the product, but only important to the individual. The attributes are related to the properties of the product, such as importance, necessity, uniqueness. Attribution in consumption has associative nature, that is, the attributes of the product are not only objectively defined characteristics, but also those that exist in the imagination, the understanding of an individual. In statistics, for example, qualitative attributes are recognized as attributes that do not have a numerical expression.

Thus, "the consumer's attitude to the product is considered as a function of the individual's belief that the objects have some characteristics that have a certain meaning for the consumer." [1]. To date, this the dominant meaning of the term "attribute" in marketing, and in general, it corresponds to its use in English: according to the dictionary, "attribute" is any somebody's or something's characteristic inherent or attributed to them.

The multi-attribute product model (according to Fishbein and Rosenberg [4]) puts the product as a set of attributes, some of which are perceived as more important, those others. The seller's task is to identify the attributes that are important for most consumers (their significant amount). On the other hand, the attribute is not important on its own; it should be a reflection of certain benefits to the consumer (functional, social, aesthetic, ergonomic, operational and economic) [2]. This researcher emphasizes as each product has its own set of attributes, as each consumer has its own attribute system. Consequently, the same product choice can be made for different attributes, the set of which is significant for the consumer.

The term "product characteristic" is also used for the study of consumer behavior. Characteristics are any consumer-identified product feature, the process of its purchase, consumption (exploitation), utilization, to which the consumer forms certain judgment. K. Lancaster emphasized that "goods, as such, are not immediate objects of preference or utility or welfare, but have associated with them characteristics which are directly relevant to the consumer," [5] that is, with his pleasure, and assumed that the characteristics of the product should be defined not in terms of the reaction of consumers to them, but as a result of their objective measurement.

But the differences interpretation of the terms "attribute" and "characteristic" are not of fundamental importance for this study, therefore, further the term product or service "characteristics" is used in the broad sense. 
Taking into account the characteristics of the goods given above, we will conduct a study of the results of personal sales of different for types and purposes goods, during which several sellers presented their goods consistently to one audience of potential buyers, processed objections, entered into agreements for the purchase of goods. The audience ( 23 people) was chosen arbitrarily and it is fairly homogeneous (by age, lifestyle, income level, occupation).

The following products were offered to potential consumers:

"Faculty" - mobile application, which provides informational and organizational services for consumers in providing education area, based on the latest technology and had a higher level of originality.

"ZubOK" - chewing toothpaste is intended for rapid cleaning of the oral cavity in the absence of time and the absence of special devices conditions for this. Has a higher level of novelty, there are no analogues of this product, there are substitutes products, but they inferior to the functionality of this product.

UGGold - ugg boots are a kind of shoes, seasonal goods, it has low level of novelty; it is created to provide comfort and warmth to the consumer.

"Syrup" - a service of sudden vacation. The company provides services of a fast organization various kinds of rest or holidays outside the city, in the park and other places with the full equipment provision for active recreation, depending on the consumer's wishes. It has a higher level of novelty.

"MatchUp" is a detox drink aimed at maintaining the health and good physical form of the consumer. Medium level of novelty.

"Energon" is a charger in the form of a bracelet which charging the phone through a bluetooth headset, has a higher level of novelty, analogues at the moment does not exist.

According to the estimation of the goods and services characteristics by experts of the enterprises-manufacturers, the following results are obtained: the 1st point on the importance for consumers of product characteristics is the quality, on the 2nd is the price, on the 3rd is the functionality, on the 4th is the category of the goods, on the 5th is the satisfaction with the purchase. For services, the ranking of characteristics is different from the material goods: on the 1st place is the quality of service, on the 2 nd is the price, on the 3rd is reputation, on the 4th is reliability, on the 5th is efficiency, on the 6th is satisfaction from consumption, on the 7 th is prestige.

According to observations during the speeches of the sellers a Table 1 was drawn which showing what product characteristics were highlighted during the selling.

Table 1 - Availability of information about characteristics during the presentation of a product / service

\begin{tabular}{|c|c|c|c|c|c|c|c|c|}
\hline \multirow{3}{*}{$\begin{array}{l}\text { Name of } \\
\text { product }\end{array}$} & \multicolumn{8}{|c|}{ Inherent characteristics } \\
\hline & \multicolumn{5}{|c|}{ For all types of product } & \multicolumn{3}{|c|}{ For services } \\
\hline & $\begin{array}{l}\text { Functionalit } \\
\mathrm{y}\end{array}$ & Quality & Price & $\begin{array}{l}\text { Product } \\
\text { category }\end{array}$ & $\begin{array}{l}\text { Pleasantnes } \\
\text { s purchase }\end{array}$ & $\begin{array}{l}\text { Effectiven } \\
\text { ess }\end{array}$ & $\begin{array}{l}\text { Reliabili } \\
\text { ty }\end{array}$ & $\begin{array}{l}\text { Reputat } \\
\text { ion }\end{array}$ \\
\hline $\begin{array}{l}\text { Mobile } \\
\text { application }\end{array}$ & Present & Present & Present & None & None & & & \\
\hline $\begin{array}{l}\text { Chewing } \\
\text { toothpaste }\end{array}$ & Present & Present & Present & None & None & & & \\
\hline UGG boots & Present & Present & Present & Present & None & & & \\
\hline $\begin{array}{l}\text { Service of } \\
\text { sudden vacation }\end{array}$ & Present & Present & Present & Present & Present & Present & None & None \\
\hline Detox drink & Present & Present & Present & None & None & & & \\
\hline Bracelet-charger & Present & None & Present & Present & Present & & & \\
\hline \multicolumn{6}{|c|}{ Source: prepared by the authors } & & & \\
\hline
\end{tabular}


We will conduct a ranking according to the lexicographic method of research to evaluate the importance of characteristics. The lexicographic method involves that the available set of criteria is ordered according to importance. For comparable objects, values are first measured by the most important criterion. The best object is that one whose value of this criterion is greater. In the case when the values of the comparable objects are the same, it should shift to a comparison on the basis of the next by importance criterion. The procedure ends with the iteration, in which it is possible to arrange objects by advantage, or when comparisons have been performed according to all the criteria. The expression of the characteristics is measured in increments of 1 to 5 points.

We will proceed to the selection on the basis of compensatory and non-compensatory rules of the purchase decisions.

Compensatory rules allow "replacement" of the poor implementation of some characteristics on the good implementation of others in the overall assessment of value; the disadvantage can be offset by the benefits. The principle of compensation for a product is a pattern that consists in segregate the good's characteristics present in the product and acceptable to the consumer according to the parameters that prevail over the other. This allows to some extent give way to other characteristics and properties.

The main feature of compensatory rules is that a compromise is allowed when choosing a product. This happens when the good's advantages offset its disadvantages. The results of the selection are presented in the Table 2 and Table 3.

Table 2 - Results of the choice by the rule of simple addition

\begin{tabular}{|c|c|c|c|c|c|c|}
\hline \multirow{2}{*}{ Characteristic } & \multicolumn{5}{|c|}{ Assessment of characteristics } & \multirow{2}{*}{ Choice } \\
\cline { 2 - 6 } & $\begin{array}{c}\text { Mobile } \\
\text { application }\end{array}$ & $\begin{array}{c}\text { Chewing } \\
\text { toothpaste }\end{array}$ & $\begin{array}{c}\text { Ugg } \\
\text { boots }\end{array}$ & $\begin{array}{c}\text { Detox } \\
\text { drink }\end{array}$ & $\begin{array}{c}\text { Bracelet- } \\
\text { charger }\end{array}$ & \\
\hline Quality & 4 & 5 & 5 & 4 & 3 & 3 \\
\hline Price & 5 & 5 & 2 & 5 & 5 & Mobile \\
Functionality & 5 & 5 & 3 & 5 & 5 & 5 \\
\hline Product Category & 3 & 3 & 4 & 3 & 21 & \\
\hline Pleasantness purchase & 5 & 3 & 5 & 2 & 21 & \\
\hline Total & 22 & 21 & 17 & 21 & \\
\hline
\end{tabular}

Source: prepared by the authors

Table 3 - Results of the choice by the rule of weighted addition

\begin{tabular}{|c|c|c|c|c|c|c|c|}
\hline \multirow[b]{2}{*}{ Characteristic } & \multirow[b]{2}{*}{ Weight } & \multicolumn{5}{|c|}{ Assessment of characteristics } & \multirow[b]{2}{*}{ Choice } \\
\hline & & $\begin{array}{c}\text { Mobile } \\
\text { application }\end{array}$ & $\begin{array}{c}\text { Chewing } \\
\text { toothpaste }\end{array}$ & $\begin{array}{l}\text { Ugg } \\
\text { boots }\end{array}$ & $\begin{array}{c}\text { Detox } \\
\text { drink }\end{array}$ & $\begin{array}{l}\text { Bracelet- } \\
\text { charger }\end{array}$ & \\
\hline Quality & 35 & 4 & 5 & 5 & 4 & 3 & \multirow{6}{*}{$\begin{array}{l}\text { Chewing } \\
\text { toothpaste }\end{array}$} \\
\hline Price & 30 & 5 & 5 & 2 & 5 & 3 & \\
\hline Functionality & 20 & 5 & 5 & 3 & 5 & 5 & \\
\hline Product Category & 10 & 3 & 3 & 4 & 3 & 5 & \\
\hline $\begin{array}{l}\text { Pleasantness } \\
\text { purchase }\end{array}$ & 5 & 5 & 3 & 5 & 2 & 5 & \\
\hline Total & 100 & 445 & 470 & 360 & 430 & 370 & \\
\hline
\end{tabular}

Source: prepared by the authors

Non-compensation rules provide in the general case for the formation of a zero value of the product for consumer, if one or more attributes to be implemented worse than some 
threshold value. These rules of the decision do not allow the compensation for low product ratings by the one attribute through high ratings the other attribute.

1. A common or conjunctive rule. The objects that meet the minimum level for each of the attributes are selected. If at least one attribute does not match the objects' acceptable minimum, it is discarded (Table 4).

Table 4 - Results of the choice by the conjunctive rule

\begin{tabular}{|c|c|c|c|c|c|c|c|c|}
\hline \multirow[b]{2}{*}{ Characteristic } & \multicolumn{5}{|c|}{ Assessment of characteristics } & \multirow[b]{2}{*}{ Minimal } & \multirow[b]{2}{*}{$\begin{array}{l}\text { Satisfies the } \\
\text { conditions }\end{array}$} & \multirow[b]{2}{*}{ Choice } \\
\hline & $\begin{array}{c}\text { Mobile } \\
\text { applicati } \\
\text { on }\end{array}$ & $\begin{array}{l}\text { Chewing } \\
\text { toothpaste }\end{array}$ & $\begin{array}{l}\text { Ugg } \\
\text { boots }\end{array}$ & $\begin{array}{l}\text { Detox } \\
\text { drink }\end{array}$ & $\begin{array}{l}\text { Bracelet- } \\
\text { charger }\end{array}$ & & & \\
\hline Quality & 4 & 5 & 5 & 4 & 3 & 5 & 2,3 & \multirow{5}{*}{ 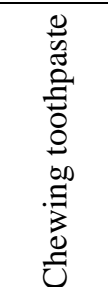 } \\
\hline Price & 5 & 5 & 2 & 5 & 3 & 4 & $1,2,4$ & \\
\hline Functionality & 5 & 5 & 3 & 5 & 5 & 5 & $1,2,4,5$ & \\
\hline $\begin{array}{c}\text { Product } \\
\text { Category }\end{array}$ & 3 & 3 & 4 & 3 & 5 & 4 & 3,5 & \\
\hline $\begin{array}{l}\text { Pleasantness } \\
\text { purchase }\end{array}$ & 5 & 3 & 5 & 2 & 5 & 3 & $1,2,3,5$ & \\
\hline
\end{tabular}

Source: prepared by the authors

2. Separate or disjunctive rule. When it chooses objects that meet the minimum requirements only by significant criteria (Table 5).

Table 5 - Results of the choice according to the disjunctive rule

\begin{tabular}{|c|c|c|c|c|c|c|c|c|c|}
\hline \multirow[b]{2}{*}{ Characteristic } & \multirow[b]{2}{*}{$\begin{array}{l}\frac{\pi}{000} \\
\frac{00}{0} \\
3\end{array}$} & \multicolumn{5}{|c|}{ Assessment of characteristics } & \multirow[b]{2}{*}{ Minimal } & \multirow[b]{2}{*}{$\begin{array}{l}\text { Satisfies the } \\
\text { conditions }\end{array}$} & \multirow[b]{2}{*}{ Choice } \\
\hline & & $\begin{array}{c}\text { Mobile } \\
\text { applicati } \\
\text { on }\end{array}$ & $\begin{array}{l}\text { Chewin } \\
\text { g } \\
\text { toothpa } \\
\text { ste }\end{array}$ & $\begin{array}{l}\text { Ugg } \\
\text { boots }\end{array}$ & $\begin{array}{l}\text { Detox } \\
\text { drink }\end{array}$ & $\begin{array}{c}\text { Bracelet } \\
- \\
\text { charger }\end{array}$ & & & \\
\hline Quality & 35 & 4 & 5 & 5 & 4 & 3 & 5 & 2,3 & \multirow{5}{*}{ 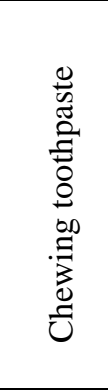 } \\
\hline Price & 30 & 5 & 5 & 2 & 5 & 3 & 4 & $1,2,4$ & \\
\hline Functionality & 20 & 5 & 5 & 3 & 5 & 5 & 5 & $1,2,4,5$ & \\
\hline $\begin{array}{l}\text { Product } \\
\text { Category }\end{array}$ & 10 & 3 & 3 & 4 & 3 & 5 & Not matter & All products & \\
\hline $\begin{array}{l}\text { Pleasantness } \\
\text { purchase }\end{array}$ & 5 & 5 & 3 & 5 & 2 & 5 & Not matter & All products & \\
\hline Total & 100 & 445 & 470 & 360 & 430 & 370 & & & \\
\hline
\end{tabular}

Source: prepared by the authors

The rule of the "elimination on the aspects". Brands are considered consistently according to the pre-ranking by importance criteria. At the beginning goods that meet the minimum allowable value of the criteria are selected, then only the goods selected in the previous step are considered (Table 6).

Thus, according to all calculations, the presence of the most important characteristics in terms of the manufacturer is the biggest for the "Chewing paste", but the choice of buyers is another. 16 of 23 people chose the product "Mobile Application" and only 11 selected "Chewable Paste". During the consumer survey in the process of presented products' sales, the following results were obtained (Table 7). 
Table 6 - Results of the choice by the rule of "elimination on the aspects"

\begin{tabular}{|c|c|c|c|c|c|c|c|c|c|}
\hline \multirow[b]{2}{*}{ Characteristic } & \multirow[b]{2}{*}{$\begin{array}{l}\frac{2}{00} \\
\frac{00}{0} \\
3\end{array}$} & \multicolumn{5}{|c|}{ Assessment of characteristics } & \multirow[b]{2}{*}{ Minimal } & \multirow[b]{2}{*}{$\begin{array}{l}\text { Satisfies } \\
\text { the } \\
\text { conditions }\end{array}$} & \multirow[b]{2}{*}{ Choice } \\
\hline & & $\begin{array}{c}\text { Mobile } \\
\text { application }\end{array}$ & $\begin{array}{l}\text { Chewing } \\
\text { toothpaste }\end{array}$ & $\begin{array}{l}\text { Ugg } \\
\text { boots }\end{array}$ & $\begin{array}{l}\text { Detox } \\
\text { drink }\end{array}$ & $\begin{array}{l}\text { Bracelet- } \\
\text { charger }\end{array}$ & & & \\
\hline Quality & 35 & 4 & 5 & 5 & 4 & 3 & 5 & 2,3 & \\
\hline Price & 30 & 5 & 5 & 2 & 5 & 3 & 4 & $1,2,4$ & $\tilde{\tilde{E}}$ \\
\hline Functionality & 20 & 5 & 5 & 3 & 5 & 5 & \multirow{3}{*}{\multicolumn{2}{|c|}{$\begin{array}{l}\text { Next are not } \\
\text { considered }\end{array}$}} & 0 \\
\hline $\begin{array}{l}\text { Product } \\
\text { Category }\end{array}$ & 10 & 3 & 3 & 4 & 3 & 5 & & & .0 \\
\hline $\begin{array}{l}\text { Pleasantness } \\
\text { purchase }\end{array}$ & 5 & 5 & 3 & 5 & 2 & 5 & & & $\stackrel{\mathscr{\theta}}{0}$ \\
\hline
\end{tabular}

\section{Source: prepared by the authors}

Table 7 - Consumer interest in the product / service

\begin{tabular}{|c|c|c|c|}
\hline $\begin{array}{l}\text { Product / } \\
\text { services } \\
\text { name }\end{array}$ & $\begin{array}{l}\text { Characteristics } \\
\text { of the goods / } \\
\text { services } \\
\text { caused interest }\end{array}$ & $\begin{array}{l}\text { How was expressed interest in this product / } \\
\text { service }\end{array}$ & $\begin{array}{l}\text { Characteristics of the } \\
\text { goods / services not } \\
\text { caused interest }\end{array}$ \\
\hline $\begin{array}{l}\text { Mobile } \\
\text { application }\end{array}$ & $\begin{array}{l}\text { Functionality } \\
\text { Price }\end{array}$ & $\begin{array}{l}\text { Consumers listened carefully to the seller. There are } \\
\text { no objections to the product after the presentation. } \\
\text { The questions concerned the conditions of } \\
\text { exploitation of this service and terms of its purchase } \\
\text { only. }\end{array}$ & $\begin{array}{l}\text { Product category } \\
\text { Satisfaction with the } \\
\text { purchase }\end{array}$ \\
\hline $\begin{array}{l}\text { Chewing } \\
\text { toothpaste }\end{array}$ & $\begin{array}{l}\text { Functionality } \\
\text { Quality }\end{array}$ & $\begin{array}{l}\text { Consumers responded positively, emotionally to the } \\
\text { slides of the presentation. At the end of the } \\
\text { presentation the seller was asked questions about the } \\
\text { ratio price-quality, place of purchase and side effects } \\
\text { of the product. }\end{array}$ & $\begin{array}{l}\text { Product category } \\
\text { Satisfaction with the } \\
\text { purchase }\end{array}$ \\
\hline Ugg boots & $\begin{array}{l}\text { Product } \\
\text { category } \\
\text { Price }\end{array}$ & $\begin{array}{l}\text { Interest in this product was poorly expressed, because } \\
\text { that product, in contrast to the other, is not a novelty. } \\
\text { But consumers who were interested in purchasing } \\
\text { this product posed questions about the ratio price- } \\
\text { quality of this product and the differences this one } \\
\text { from similar products. }\end{array}$ & Functionality \\
\hline $\begin{array}{l}\text { Service of } \\
\text { sudden } \\
\text { vacation }\end{array}$ & $\begin{array}{l}\text { Reliability } \\
\text { Functionality }\end{array}$ & $\begin{array}{l}\text { Consumers responded positively to seller's reports. } \\
\text { Most of the questions concerned the reliability of the } \\
\text { service, its independence from external factors of } \\
\text { influence and terms of delivery. }\end{array}$ & $\begin{array}{l}\text { Product category } \\
\text { Reputation of the service } \\
\text { provider }\end{array}$ \\
\hline Detox drink & $\begin{array}{l}\text { Price } \\
\text { Functionality }\end{array}$ & $\begin{array}{l}\text { Consumer's interest was discovered precisely in the } \\
\text { active work after the presentation of the product: } \\
\text { many people questioned about the functionality of } \\
\text { this product, its instructions for acceptance and its } \\
\text { response to other products, with regard to its } \\
\text { differences from analogues (coffee, phyto-tea, fat } \\
\text { burning capsules). }\end{array}$ & $\begin{array}{l}\text { Satisfaction with the } \\
\text { purchase } \\
\text { Product category }\end{array}$ \\
\hline $\begin{array}{l}\text { Bracelet- } \\
\text { charger }\end{array}$ & $\begin{array}{l}\text { Price } \\
\text { Quality }\end{array}$ & $\begin{array}{l}\text { The present products interested consumers in the fact } \\
\text { that it is an innovation in the market of electrical } \\
\text { appliances. Most of the customers' questions } \\
\text { concerned the conditions of exploitation of this } \\
\text { product, the ratio price-quality of this product, } \\
\text { guarantees and maintenance of the device. }\end{array}$ & $\begin{array}{l}\text { Satisfaction with the } \\
\text { purchase Functionality }\end{array}$ \\
\hline
\end{tabular}

Source: prepared by the authors 
According to the present characteristics of the studied goods can be divided into groups according to different criteria:

1) focus on the "quality-price" ratio, this group includes: chewing toothpaste, ugg boots and bracelet-charger.

2) focus on product functionality: Mobile application, Detox-drink.

3 ) focus on reliability (this criterion refers only to the service of sudden vacation).

Consequently, the importance of the characteristics of the product in the perception of the seller and consumer may vary. Even if the characteristic has a high level of importance, it does not prove that it will affect the choice of the consumer in a particular situation of choice. From here, for example, J.H. Myers, M. I. Alpert proposed to consider two types of importance - global (characteristic is important in principle) and local (it is important in this situation) [6]. On the other hand, the importance of the characteristics may not be taken by the consumer as such and may not influence the choice if it is present in all choices (perceived for granted).

That is, it is expedient to focus on those characteristics of the goods that will affect the choice of the buyer, and it should be understudied the differences between the importance and influence of the characteristics of the product.

In most cases, important features include existing intrinsic characteristic of the product, but their list is situational. Studies have found that the level of importance of the product's characteristics it is always a subjective assessment, which attributed to the characteristics (both verbally and mentally) by the consumer himself. An assessment of importance is usually given for the abstract purchase situation, that is, whether a characteristic is important "in principle" for purchase a product of this category [1].

Definition of the term "influence" of the characteristics of the product was first given by J.H. Myers, M. I. Alpert. They state, "Attitudes toward features which are most closely related to preference or to actual purchase decisions are said to be determinant; the remaining features or attitudes - no matter how favorable - are not determinant"[6]. So, under the influence (determinacy) of the characteristics of the product should be understood as the degree of its benefits and influence on the purchase decision. In many cases, highlighted as important characteristics do not act as influential.

A number of characteristics may have a low degree of importance (subjective, perceived) for the consumer, but in reality, make a significant impact on his choice and purchase decision. A. DiPaula and B. Justuson call these characteristics "implicit" [7]. If most important characteristics are present in all variants of the choice, then it is obvious that the choice will be made on the basis of not so essential, but required level of characteristics, called influential.

Since the evaluation of the importance and influence of the characteristics of the product depends on the consumer, it would be advisable to formulate the concept of "significance" of the characteristics of the product to predict by seller the choice of the consumer. Significance is a characteristic that determines the degree of relevancy of characteristics. Significance is aimed at the result, namely, in changing the behavior of the consumer. That is, the goal of the seller must be to giving goods the significant characteristics or their formation in the perception of the buyer.

In turn, the information used to calculate in the preparation of management decisions should be relevant. Relevance means that the data must meet the specific information needs of users. Information is relevant if it can influence to a decision. On the other hand, usually the buyer chooses what suits him in specific life situation. And this is also relevance information in terms of the consumer.

However, it is difficult to determine which information can be considered relevant, since there are no clear criteria for the relevance of the information. We can ask certain conditions for recognition the relevance of an object: 
- to consider as relevant information which relevant to this problem and able to influence the choice of the subject;

- the relevance of the information is determined depending on the object of the relationship: purpose, understanding or decision;

- untimely information cannot be relevant, it should be used to make a decision before it loses the ability to influence the decision;

- attribution of the status "relevant" to certain indicator should be based solely on the conditions of a particular situation.

The main task of using relevant information is to reduce (but not necessarily eliminate) the existing uncertainty. Thus, when dealing with consumers, there is a set of relevant information from consumers about the product or its individual characteristics and determine the non-conformity the requirements of consumers.

However, the information relevant from the seller's point of view will not always be relevant to the consumer. Significance is a characteristic that determines the degree of relevancy. Consumers, choosing even the simplest things, evaluate the many characteristics of the proposed product and react to those, which meet their expectations and understanding precisely. That is, we need a filter to understand what requires attention and what does not and, therefore, significance performs two important functions in this regard:

- sorting and provide the relevancy of characteristics, that is, the correspondence of the result obtained to the desired;

- identification of priorities for features worth paying attention to.

The tasks of analysis of product characteristics' impact on sales results are:

- determining the search area of important, influential, significant for the consumer characteristics that determine his choice;

- the assessment of the presence and severity (presence degree) of the same important characteristics compared with the competing goods;

- the definition of a list of significant characteristics;

- the assessment of the influence degree on the sale's results of characteristics that are different from the characteristics of competing goods.

The algorithm for determining the relevant characteristics of the goods/services is shown in Fig. 1.

It should be determined the parameters of the search field for significant characteristics for consumer in the form of Table 8 with the application of different approaches to the perception of the product.

The image of a product is a widespread and fairly sustainable idea of the excellent or exceptional product characteristics that give it a special uniqueness and distinguish it from a number of similar goods.

The image of the product has different manifestations, which related to different good's characteristics and reflects different consumer approaches to the product.

According to O.S. Vikhanskyi when purchasing a product that has a particular image for an additional fee for this image, the buyer indeed pays the association related with the product. At the same time, the buyer, as if buying not only the product, but also a special place of this product in the environment, which is reflected in a concentrated form in the image of a product [8]. 


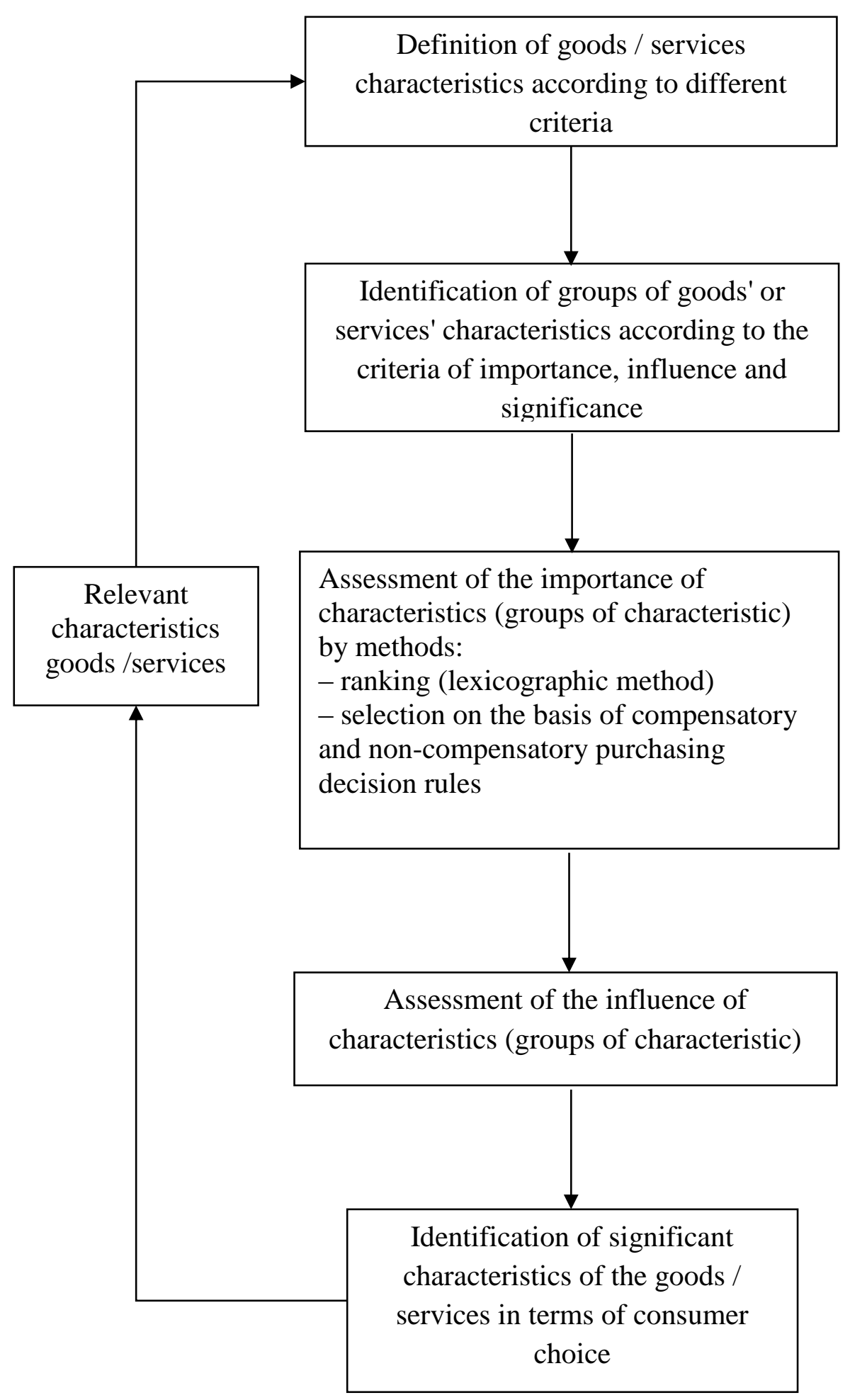

Figure 1 - The algorithm for determining the relevant characteristics of the goods/services Source: prepared by the authors 
Table 8 - Different approaches to the perception of the product

\begin{tabular}{|c|c|c|c|c|c|}
\hline \multicolumn{6}{|c|}{ Goods/services attributes } \\
\hline $\begin{array}{l}\text { According } \\
\text { to the } \\
\text { image } \\
\text { approach }\end{array}$ & $\begin{array}{l}\text { According to } \\
\text { the consumer } \\
\text { approach }\end{array}$ & $\begin{array}{l}\text { According to } \\
\text { the } \\
\text { motivational } \\
\text { approach } \\
\text { (psychoanalytic } \\
\text { model) }\end{array}$ & $\begin{array}{l}\text { According } \\
\text { to the } \\
\text { marketing- } \\
\text { mix }\end{array}$ & $\begin{array}{l}\text { According } \\
\text { to the model } \\
\text { of the } \\
\text { cognitive } \\
\text { structure of } \\
\text { the } \\
\text { consumer }\end{array}$ & $\begin{array}{l}\text { According to } \\
\text { the "model of } \\
\text { significance" }\end{array}$ \\
\hline $\begin{array}{l}\text { The product } \\
\text { has better } \\
\text { qualities than } \\
\text { competing } \\
\text { goods }\end{array}$ & $\begin{array}{l}\text { Consumer } \\
\text { functions and } \\
\text { properties of } \\
\text { the goods, } \\
\text { which } \\
\text { determine the } \\
\text { type of goods, } \\
\text { its belonging to } \\
\text { a certain } \\
\text { commodity } \\
\text { group }\end{array}$ & $\begin{array}{l}\text { Utilitarian } \\
\text { characteristics } \\
\text { (operational) }\end{array}$ & $\begin{array}{l}\text { Characteristics } \\
\text { of the product }\end{array}$ & $\begin{array}{l}\text { Attributes of the } \\
\text { goods }\end{array}$ & $\begin{array}{l}\text { "Rational" } \\
\text { characteristics }\end{array}$ \\
\hline $\begin{array}{l}\text { The product } \\
\text { is presented } \\
\text { with special } \\
\text { qualities }\end{array}$ & \multirow{5}{*}{$\begin{array}{l}\text { Characteristics } \\
\text { that satisfy the } \\
\text { specific needs } \\
\text { of a particular } \\
\text { consumer }\end{array}$} & $\begin{array}{l}\text { Esthetic } \\
\text { characteristics }\end{array}$ & $\begin{array}{l}\text { Characteristics } \\
\text { of the price }\end{array}$ & $\begin{array}{l}\text { Abstract product } \\
\text { characteristics }\end{array}$ & \multirow{5}{*}{$\begin{array}{l}\text { "Emotional" } \\
\text { characteristics:- } \\
\text { values } \\
\text { - social } \\
\text { - sensory }\end{array}$} \\
\hline $\begin{array}{l}\text { The product } \\
\text { expression } \\
\text { the buyer } \\
\text { status }\end{array}$ & & $\begin{array}{l}\text { Motives of } \\
\text { prestige }\end{array}$ & $\begin{array}{l}\text { Characteristics } \\
\text { of the place of } \\
\text { purchase / } \\
\text { consumption }\end{array}$ & $\begin{array}{l}\text { The functional } \\
\text { consequences of } \\
\text { the goods }\end{array}$ & \\
\hline \multirow[t]{3}{*}{$\begin{array}{l}\text { The product } \\
\text { has an } \\
\text { exceptional } \\
\text { distinction } \\
\text { (uniqueness, } \\
\text { originality) }\end{array}$} & & $\begin{array}{l}\text { Motives of } \\
\text { assimilation, } \\
\text { achievement of } \\
\text { the ideal } \\
\text { (conformity to a } \\
\text { certain image) }\end{array}$ & \multirow[t]{3}{*}{$\begin{array}{l}\text { Characteristics } \\
\text { of the } \\
\text { distribution } \\
\text { process }\end{array}$} & $\begin{array}{l}\text { The } \\
\text { psychological } \\
\text { consequences of } \\
\text { the product }\end{array}$ & \\
\hline & & \multirow[t]{2}{*}{$\begin{array}{l}\text { The motives of } \\
\text { tradition }\end{array}$} & & $\begin{array}{l}\text { The } \\
\text { characteristics is } \\
\text { valuable in } \\
\text { themselves } \\
\text { (terminal) }\end{array}$ & \\
\hline & & & & $\begin{array}{l}\text { The } \\
\text { characteristics } \\
\text { which used to } \\
\text { achieve } \\
\text { common goals } \\
\text { (instrumental) }\end{array}$ & \\
\hline
\end{tabular}

Source: prepared by the authors

The seller because of the features of his position in relation to the product mainly sees the product through the prism of the first subgroup of consumer properties. The buyer, in turn, mainly perceives consumer properties as belonging to the second subgroup. Recently there is a tendency to change the ratio in the direction of increasing the proportion of the second subgroup. Therefore, for a successful operation, the firm must increasingly consider the consumer qualities of its products as they are perceived by the consumer, not the producer.

O. Vikhansky proposes to consider the product as a set of characteristics of what the firm sells and that the customer buys [9]. Therefore, it is very important to keep in mind that the goods are not what is being produced, but what the customer is buying, what he pays for.

The psychoanalytic model emphasizes the attitude of people towards things and accordingly recommends to influence this attitude or to change it in such a way as to motivate

V. Atiushkina, A. Zhekul. Analysis of the impact of goods characteristics on the results of 45 personal selling 
the purchase of a product or service. The marketing-mix factors according to $\mathrm{Ph}$. Kotler [10] are a powerful incentive for buying decisions, but not enough for the consumer to make a choice. In addition, it is influenced by psychological, socio-cultural and situational factors.

M. Johnson formulated a model of the cognitive structure of the consumer, which consist of six levels: "Attributes of the goods - Abstract product characteristics - The functional consequences of the goods - The psychological consequences of the product - The characteristics is valuable in themselves (terminal) - The characteristics which used to achieve common goals (instrumental)" [11].

The most important conclusion of the model is that the greatest importance in consumer behavior is not the physical properties of the product, but the perception of the product as a set of values - utilitarian and symbolic (i.e., terminal, instrumental).

The "Model of Significance", proposed by A. Covill, P. Braun, identifies four groups of meaningful factors of consumer choice, each of which corresponds to a certain approach to the perception of the product [3]. The first one has an orientation towards the "rational" characteristics of the product: price, functionality, place of purchase etc.; the other three group "emotional" characteristics - value (they are associated with important values, corresponding to consumer persuasion), social (they are emphasizes belonging to the social group, to a certain way of life), sensory (such as comfort, security, order, image) $[12,13,14,15]$.

It should be concluded that the characteristics of a good / service that are of a high degree of importance but present in similar goods, as well as influential characteristics that is distinguish for similar goods and reflect the client's situational needs, can be determine as significant in the buyer's point of view. Determining the set of significant characteristics requires further study taking into account the characteristics of different types of goods.

We will conduct an assessment of the significance of the services on the example of the service «Syrup» (sudden rest) which defined in the previous stages of this study. As the characteristics that can influence the choice of the consumer, the efficacy of the service, the reliability of the service and the reputation of the company are taken. It is used the method of correlation-regression analysis and programmatic capabilities Excel (calculation of model parameters using the "Data Analysis" application) for primary statistical processing of measurement results, analytical description of the results of the experiment.

The input data of the evaluation are: the number of observations, $y$ - the number of purchases per day, $X_{1}$ - the percentage of consumers among the total number of potential buyers who have chosen as the most significant characteristic of "efficiency", $\mathrm{X}_{2}$ - the choice of the characteristic of "reliability" (in percent), $\mathrm{X}_{3}$ - the choice of the characteristic of "reputation"(in percent). Input data are summarized in Table 9.

The free member (shift) $b_{0}$, equal to $-8,883$, is formally to be understood as follows - in the absence of evaluated characteristics of the service, sales volume is reduced. In general, the shift $b_{0}$ should be taken as an auxiliary value needed for optimal predictions, but it not be interpreted literally.

The regression coefficients $b_{1}, b_{2}, b_{3}$ should be considered as the degree of influence of each of the variables (service efficiency, reliability, company reputation) on the sales if all other independent variables remain unchanged. Thus, the coefficient $b_{1}$, equal to 0.224 , indicates that (in other equal terms) an increase the frequency of the choice of the characteristic "efficiency" on $1 \%$ leads to an increase in sales of services by $22.4 \%$; similarly, $\mathrm{b}_{2}$ is responsible for increasing reliability by $14.5 \%$ and $b_{3}$ - for company reputation by $31.6 \%$.

Thus, for the considered example, the regression equation (or prediction equation) will have the following form:

$$
\hat{y}=b 0+b_{1} x_{1}+b_{2} x_{2}+b_{3} x_{3}=-8,883+0,224 \mathrm{x}_{1}+0,145 \mathrm{x}_{2}+0,316 \mathrm{x}_{3}
$$


Table 9 - Input data of correlation-regression analysis

\begin{tabular}{|c|c|c|c|c|}
\hline $\begin{array}{c}\text { The number of } \\
\text { observations }\end{array}$ & $y$, purchases per day & $\mathrm{X}_{1}, \%$ & $\mathrm{X}_{2}, \%$ & $\mathrm{X}_{3}, \%$ \\
\hline 1 & 12 & 40 & 38 & 15 \\
\hline 2 & 8 & 25 & 22 & 20 \\
\hline 3 & 16 & 37 & 45 & 30 \\
\hline 4 & 10 & 22 & 26 & 25 \\
\hline 5 & 12 & 45 & 30 & 20 \\
\hline 6 & 14 & 36 & 35 & 25 \\
\hline 7 & 9 & 20 & 27 & 30 \\
\hline 8 & 6 & 25 & 35 & 25 \\
\hline 9 & 10 & 30 & 35 & 20 \\
\hline 10 & 10 & 30 & 25 \\
\hline
\end{tabular}

Source: prepared by the authors

In order to evaluate the validity of our regression analysis, we draw the standard error $\left(S_{u}\right)$ techniques, which gives an idea of the approximate magnitude of the prediction error, and the determination coefficient $\left(\mathrm{R}^{2}\right)$. It indicates which percentage of the variation of the function is due to the influence of the factors $\mathrm{x}_{\mathrm{k}}$. The results of the calculation of statistical indicators of regression are given in Table 10.

Table 10 - Results of calculation of statistical indicators of regression

\begin{tabular}{|c|c|c|c|c|}
\hline \multicolumn{5}{|c|}{ Regression statistics } \\
\hline Multiple R & \multicolumn{4}{|l|}{0,909717} \\
\hline R-square & \multicolumn{4}{|l|}{0,827585} \\
\hline $\begin{array}{l}\text { Normalized R- } \\
\text { square }\end{array}$ & \multicolumn{4}{|l|}{0,741377} \\
\hline Standard error & \multicolumn{4}{|l|}{1,593816} \\
\hline Observation & \multicolumn{4}{|l|}{10} \\
\hline $\begin{array}{l}\text { Dispersion } \\
\text { analysis }\end{array}$ & $F$ & Significance F & & \\
\hline \multicolumn{5}{|l|}{ Regression } \\
\hline & Coefficients & Standard error & t-statistics & P-values \\
\hline Y-intersection & $-8,883$ & 3,830 & $-2,319$ & 0,060 \\
\hline $\mathrm{X}_{1}$ & 0,224 & 0,063 & 3,549 & 0,012 \\
\hline $\mathrm{X}_{2}$ & 0,145 & 0,083 & 1,744 & 0,132 \\
\hline $\mathrm{X}_{3}$ & 0,316 & 0,113 & 2,801 & 0,031 \\
\hline
\end{tabular}

Source: prepared by the authors

The results of the statistical evaluation show that the standard error for the function is 1.59. This result, in relation to our example, should be considered as follows: the actual amount of sales of services differs from the projected figures by no more than 1.59 purchases per day.

The determination coefficient $\mathrm{R}^{2}$ is 0.83 , which is $83 \%$. This result should be interpreted as follows: all investigated factors explain $83 \%$ variation of the analyzed function (sales volume). 
The validity of the model consists of the following sequence of actions. We will make an F-criterion check. The computer printout gave us the value of F, equal to 9.6. For the analysis of the equation, we will use the value of $\mathrm{F}_{\text {calc }}$, the inverse of the presented Excel calculation. It will be 0.104 . We find the critical value of $F_{\text {crit }}$ under the reference table, provided that for the numerator the degree of freedom $\mathrm{f}_{1}=\mathrm{k}$, that is, it will be 3 (the number of influencing factors), and for the denominator $f_{2}=n-k-1=6$. Then we will have the following values for $F_{\text {crit: }} 4.76$. The ratio of $F_{\text {calc }}<F_{\text {crit }}$ is executed, so we can confidently speak of the high degree of adequacy of the analyzed equation.

Verification with using the significance level $\alpha$. In fact, it has been determined that $\alpha=$ 0.01. This suggests that the dependence of this function $y$ (value of service sales) on the influence factors $x_{1}, x_{2}$ and $x_{3}$ is really stable, that is, the volume of sales is not purely random value.

Verification with using the coefficient of determination. According to our evaluations, the determination coefficient $\mathrm{R}^{2}$ is 0.83 or $83 \%$. The test table at the level of significance of $5 \%$ in the case of a sample of $n=10$ and the number of variables $k=3$ gives the critical value $R_{\text {crit }}^{2}$ $=0.704$. Since the ratio $R_{\text {calc }}^{2}>R_{\text {crit }}^{2}$ is executed, then with the probability of $95 \%$ it can be argued that this regression equation is significant. As you can see, all methods of statistical verification confirm the validity of the model.

The verification of the adequacy of the regression coefficients is performed using the $t$ criterion. The analyzed factor is considered significant if its $t$-criterion in absolute value exceeds 2.00 (more precisely 1.96), which corresponds to a significance level of 0.05 . In our example we have for the coefficients $b_{0}, b_{1}, b_{2}, b_{3}$ the following indicators of Student's criterion: $t_{b 0}=-$ $2,32, \mathrm{t}_{\mathrm{b} 1}=3.55, \mathrm{t}_{\mathrm{b} 2}=1.74, \mathrm{t}_{\mathrm{b} 3}=2.8$. From all of the foregoing, it follows that not all coefficients of our equation are significant. The coefficient $t_{\mathrm{b} 2}$ does not meet the criterion, is not statistically significant and cannot characterize the degree of influence on the end result. That is, the interpretation of the influence of the "reliability" characteristic needs to be clarified through further explored.

Conclusions from this research and prospects for further developments in this area. In the study of the relationship between the characteristics of the product and the results of personal selling it was found that not all characteristics of the goods have a direct influence on the consumer's decision to buy. This is due to the presence of characteristics, the importance of which for the consumer has a different degree, the influence of which is limited by the presence of similar characteristics of analogues, as well as the possibility to determine the significant characteristics of the product. On an example of the sudden vacation service "Syrup", the evaluation of the influence of significant characteristics (service efficiency, reliability, company reputation) on the result of the sale was carried out.

To identify significant features of the product developed a search area, which is composed on the basis of different approaches to the classification of characteristics of the product (services); also an algorithm for determining the relevant characteristics of the product was formed. These questions require a more detailed and in-depth study, namely towards the elaboration of a list of important characteristics; the composition of characteristics' groups on the basis of similarity; the definition of the method for evaluating the significance of the product's characteristics; setting criteria for the relevance of the data.

1. Gladkih I.V., \& Svetlanova ZH.V. (2006). Izmerenie znachimosti harakteristik tovara v marketingovyh issledovaniyah [Measuring the importance of product characteristics in marketing research]. Vestnik Sankt-Peterburgskogo universiteta - Bulletin of St. Petersburg University, 8, 2, 65-87 [in Russian]. 
2. Posypanova, O.S. (2012). Ekonomicheskaya psihologiya: psihologicheskie aspekty povedeniya potrebitelej. Monografiya. [Economic psychology: psychological aspects of consumer behavior. Monograph]. Kaluga: iz-vo KGU im. K.E. Ciolkovskogo [in Russian].

3. Coville, A., \& Braun, P. (2015). Relevantnost'. Sila, kotoraya menyaet vzglyady i povedenie potrebiteley i pozvolyaet vsegda operezhat' konkurentov [Relevance. The force that changes the views and behavior of consumers and always allows you to stay ahead of competitors]. Moscow: AzbukaBiznes [in Russian].

4. Fishbein, M. (1963). An Investigation of the Relationships between Beliefs about an Object and the Attitude toward that Object. Human Relations, 16, 233-239. Retrieved from: https://journals.sagepub.com/doi/10.1177/001872676301600302.

5. Lancaster, K. (1966). Change and Innovation in the Technology of Consumption. The American Economic Review, 56, 1/2, 14-23.

6. Myers, J.H., \& Alpert, M.I. (1968). Determinant Buying Attitudes: Meaning and Measurement. Journal of Marketing, 32, 13-20.

7. DiPaula, A., \& Justason, B. (2003). Integrating Explicit and Implicit Approaches. Quirk's Marketing Research Review. Retrieved from: http:// www.quirks.com.

8. Rajko, D.V., \& Cejtlin L.M. (2016). Marketynghove zabezpechennja spozhyvacjkoji pryvablyvosti tovaru promyslovogho pryznachennja [Marketing provision of consumer attractiveness of industrial goods]. Marketyngh i menedzhment innovacij - Marketing and Innovation Management, 1, 22-31 [in Ukrainian].

9. Vikhanskyi, O.S. (2006). Strategicheskoe upravlenie [Strategic management]. Moscow: Ekonomist [in Russian].

10. Kotler, Ph. (1967). Marketing Management: Analysis, Planning and Control. Englewood Cliffs, N.J.: Prentice-Hall.

11. Johnson, M.D. (1989). On the Nature of Product Attributes and Attribute Relationships. Advances in Consumer Research. 16, 1, 598-604.

12. Oklander, M.A., Oklander, T.O., \& Yashkina, O.I. (2017). Tsyfrovyi marketynh - model marketynhu XXI storichchia [Digital Marketing - The Marketing Model of the 21st Century]. Oklander, M.A. (Ed.). Odesa [in Ukrainian].

13. Oklander, M.A. (2002). Problemy formuvannia marketynhovoi systemy krainy [Problems of the formation of the country's marketing system]. Kyiv: Naukova dumka [in Ukrainian].

14. Oklander, M.A., Oklander, T.O., Pedko, I. A., \& Yashkina, O.I. (2017). Marketynhovi doslidzhennia innovatsii ta pidpryiemnytski ryzyky [Marketing Research Innovations and Business Risks]. Oklander, M.A. (Ed). Odesa: Astroprint [in Ukrainian].

15. Oklander, T.O. (2011). Innovatsiini metody vplyvu na spozhyvachiv: aromamarketynh [Innovative methods of influencing consumers: aroma marketing]. Marketynh i menedzhment innovatsii-Marketing and management of innovations, 3, 97-101 [in Ukrainian].

B.B. Атюшкіна, кандидат економічних наук, доцент кафедри економіки $i$ підприємництва, Східноукраїнський національний університет ім. Володимира Даля (Сєвєродонеиьк, Україна).

А.А. Жекул, студентка кафедри маркетингу, Одеський національний політехнічний університет (Одеса, Україна).

\section{Аналіз впливу характеристик товарів на результати особистого продажу.}

У статті розглянуто взаємозв'язок між характеристиками товару $i$ результатами його продажу, виявлено напрямки пошуку релевантних характеристик товару. Проаналізовано характеристики продукиії, визначені за результатами опитування споживачів у прочесі персонального продажу, за ознаками важливості, впливовості та значущьості. $B$ роботі запропонований алгоритм визначення релевантних характеристик продукту (послуги) з метою збільшення обсягу продажу в прочесі персонального продажу. Для виявлення суттєвих характеристик продукту

V. Atiushkina, A. Zhekul. Analysis of the impact of goods characteristics on the results of 49 personal selling 
розроблена область пошуку, яка базується на різних підходах до класифікаиіі характеристик продукту (послуг). Здійснено на окремому прикладі оцінювання впливу суттєвих характеристик (ефективність послуг, надійність, репутація компанії) на результат персонального продажу.

Ключові слова: релевантні характеристики, алгоритм, персональний продаж, впливовість, важливість, значущість.

Received to the editor January 31, 2019. 